\title{
Hemşirelik Öğrencilerinin Bakım Planı Hazırlamada Yaşadıkları Güçlüklerin Kök Nedenlerinin İncelenmesi
}

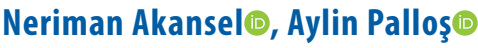

Uludağ Üniveristesi Sağlık Bilimleri Fakültesi, Hemşirelik, Bursa, Türkiye

Neriman Akansel, Doç. Dr. Aylin Palloş, Öğr. Gör. Dr.
Iletişim:

Doç. Dr. Neriman Akansel

Uludağ Üniveristesi Sağllk Bilimleri Fakültesi,

Hemşirelik, Bursa, Türkiye

Tel: +90 2242942456

E-Posta: nakansel@uludag.edu.tr
Gönderilme Tarihi :

Revizyon Tarihi :

Kabul Tarihi : :

Çevrimiçi Yayın Tarihi:
28 Ağustos 2018

22 Ekim 2018

23 Ekim 2018

04 Mart 2020
ÖZET

Amaç: Bu araştırmanın amacı hemşirelik öğrencilerinin hemşirelik bakım planlarını hazırlarken yaşadıkları güçlïkleri belirlemektir.

Çalışma Planı: Bu çalışma 2015-2016 Eğitim öğretim yılı güz yarıylında Hemşirelik Süreci dersini alan ve araştırmaya katılmaya gönüllı̈ olan ve ikinci snnıfa kayıtlı bulunan 52 hemşirelik öğrencisi ile gerçekleştirilen tanımlayıc t tipte bir araştırmadır. Araştırma verilerinin toplanmasında, balık kılçı̆ı yöntemi kullanıldı. Öğrencilerden balık kılı̧ı̆ı̆ı diyagramı üzerinde bakım planı yaparken yaşadıkları güçlüklerin nedenlerini dört temel başlık altında (insanlar, metot, materyal ve çevre) belirlemeleri ve bunu dönem ödevi olarak teslim etmeleri istendi. Verilerin değerlendirilmesinde SPSS 20,0 programı kullanııdı, sonuçlar sayı ve yüzde olarak verildi.

Bulgular: Araştırmada, öğrenci hemşirelerin hasta bakım planlarının oluşturulmasında insan, metod, malzeme ve çevre ile ilişkili güçlükler yaşadıkları görüldü. "Innsanlar” ile ilişkili en fazla yaşanan güçlüklerin bilgi eksikliği $(\% 58,18)$, hasta ile iletişim kurmada güçlük $(\% 47,27)$, hastaların öğrenciye bilgi vermemesi (\%44,2), öğretim elemanlarının yüksek beklentileri $(\% 12,73)$, klinik hemşirelerinin tutumları $(\% 29,09)$ olduğu; "metod" ile ilişkili en fazla yaşanan güçlüklerin hemşirelik öğrencilerinin analitik düşünme becerilerinde eksiklik hissetmesi $(\% 29,09)$ ve zamanı iyi kullanamamaları $(\% 27,27)$; "malzeme” ile ilişkili en fazla yaşanan güçlüğün klinik uygulamada kullanılan veri toplama formlarının uzun ve kapsamlı olması (\%23,63); "çevre" ile ilişkili en fazla yaşanan güçliuğün ise klinik uygulama ortamında bakım planının etkin şekilde kullanıımaması $(\% 49,09)$ olduğu saptandı.

Sonuç: Hemşirelik öğrencilerinin bakım planı oluștururken sorun yaşadığı alanlar farkııık göstermekle birlikte, bakım planlarının klinik ortamda etkin kullanılmasında ve öğrenciler tarafından daha kolay öğrenilmesine yönelik düzenlemelerin yapılmasında yarar olduğu düşünülmektedir.

Anahtar sözcükler: Hemşirelik süreci, hemşirelik öğrencileri, hemşirelik bakım planı, kök neden analizi

DIFFICULTIES EXPERIENCED BY NURSING STUDENTS IN THE DEVELOPMENT OF NURSING CARE PLANS: ROOT CAUSE ANALYSIS

\section{ABSTRACT}

Aim: The aim of this study was to determine the difficulties experienced by nursing students when developing nursing care plans.

Methods: This descriptive study was conducted with 52 second-year nursing students who enrolled in the Nursing Process Course in the 2015-2016 fall term. Data were collected using a fishbone diagram. Nursing students were asked to place difficulties they experience when developing nursing care plans on the fishbone diagram under four headings (people, methods, materials and environment) as a term project. Data were analysed by using SPSS 20.00 and results were given in numbers and percentages.

Results: In this study, it was determined that nursing students experienced difficulties related to people, methods, materials and environment in forming the patient care plans. It was found that knowledge deficiency of students (58.18\%), difficulty in communicating with the patients (47.27\%), patients' reluctance to share information (44.2\%), high expectations of the faculty members $(12.73 \%)$, attitudes of the clinic nurses (29.09\%) were the most important difficulties under the "people" heading. Not being able to use analytical thinking (29.09\%) and insufficient time management (27.27\%) were the most important difficulties experienced by students and classified under the "methods" heading. The length and extensivity of the data collection forms used in clinical settings by student nurses $(23.63 \%)$ was the most important difficulty under the "materials" heading. Not being able to see effective use of nursing care plans in a clinical environment (49.09\%) was the most important difficulty which was classified under the "environment" heading.

Conclusion: Although there are several areas that nursing students experience difficulties in when developing nursing care plans. Arrangements should be done to facilitate efficient use of nursing care plans in clinical practice and ensure nursing students to learn developing nursing care plans easily.

Keywords: Nursing process, nursing students, nursing care plans, root cause analysis 
P rofesyonel hemşirelik eğitimi kuramsal ve uygulamalı eğitim-öğretimi kapsayan, teorik bilgi ve becerilerin kazandırıldığı bir süreçtir $(1,2)$. Hemşirelik süreci, uygulamalı hemşirelik eğitiminin önemli bir parçasını oluşturmakta ve hemşirelik eğitimi sırasında öğrencilerden hemşirelik sürecini kullanma becerisini kazanmaları beklenmektedir $(2,3)$.

Dünya Sağlık Örgütü hemşirelik sürecini; "sağlıklı/hasta bireyin, ailenin ve toplumun bakım gereksinimlerinin/ sorunlarının belirlenmesi, gerekli hemşirelik girişimlerinin planlanması, uygulanması ve sonucun değerlendirilmesi aşamalarından oluşan sistemli bir yaklaşım olarak tanımlamaktadır" (4). Sağlıklı hasta bireyin genel sağlık durumuna ilişkin sistemli ve sürekli verilerin toplanması tanılama aşaması ile başlamaktadır. Elde edilen veriler eleştirel düşünme becerileri kullanılarak analiz edilmekte ve bireyin sağlık sorununa yönelik hemşirelik tanıları belirlenmektedir. Belirlenen hemşirelik tanıları doğrultusunda bireye özgü, bütüncül hemşirelik bakımının nasıl uygulanacağı planlanmakta ve sonraki adım olan uygulama aşamasında planlanan girişimler gerçekleştirilmektedir. Değerlendirme aşamasında ise uygulanan girişimlerin etkinliği ve bireyin bunlara yanıtı değerlendirilmektedir (5).

Profesyonel hemşirelik uygulamalarına rehber niteliğinde olan hemşirelik süreci, sağlık bakımı hizmetlerinin kalitesini arttırmaktadır. Hemşireler, bireyin karşılayamadığı gereksinimleri konusunda bireye yardımcı olurken, hemşireliğin görev ve yasal sorumluluğu olan bakım ve bakımın kaydı için de bilimsel bir araç olan hemşirelik sürecini kullanırlar (4-7). Hemşirelik bakımında hemşirelik sürecinin kullanılması hemşirelerin problem çözme ve karar verme, eleştirel düşünme becerilerini geliştirmektedir (8). Ayrıca çeşitli yasal mevzuatlarda da hemşirelik sürecinin kullanılması ile ilişkili hemşirenin görev, yetki ve sorumlulukları tanımlanmıştır. 2007 tarih ve 6283 sayılı Hemşirelik Kanunu'nun 4. maddesine (Değişik: 25/4/2007-5634/3 md.) göre; hemşireler, "her ortamda bireyin, ailenin ve toplumun hemşirelik girişimleri ile karşılanabilecek sağlıkla ilgili ihtiyaçlarını belirlemek ve hemşirelik süreci kapsamında belirlenen ihtiyaçlar doğrultusunda hemşirelik bakımını planlamak, uygulamak, denetlemek ve değerlendirmekle yükümlü sağlık personeli" olarak tanımlanmıştır (9). 08/03/2010 tarih ve 27515 sayılı Resmi Gazetede yayınlanan Hemşirelik Yönetmeliğinin 6. Maddesinde hemşirenin rol ve sorumluluklarından birinin her ortamda bireyin, ailenin ve toplumun hemşirelik girişimleri ile karşılanabilecek sağlıkla ilgili ihtiyaçlarının belirlenmesi ve hemşirelik tanılama süreci kapsamında belirlenen ihtiyaçlar çerçevesinde hemşirelik bakımının kanıta dayalı olarak planlanması, uygulanması, değerlendirilmesi ve denetlenmesi olduğu belirtilmiştir (10). 2011 yılında T. C. Sağlık Bakanlığı Performans Yönetimi Kalite Geliştirme Daire Başkanlığı tarafından oluşturulan Hastane Hizmet Kalite Standartları kapsamında da hemşirelerin hasta gereksinimleri doğrultusunda bakım planı düzenlenmesi gerektiği ele alınmıştır. Hemşirelerin bakım planına; hastanın bakım gereksinimleri ve buna yönelik hedeflerin, uygulamalar ve uygulama sonuçlarının değerlendirilmesinin kayıt edilmesi bir gerekliliktir (11). Hemşirelik sürecinin yararları ve yasal düzenlemeler, hemşirelik sürecinin öğretimini zorunlu kılmaktadır $(7,12)$. Hemşirelik sürecinin önemi, amacı, nasıl uygulanacağı hemşirelik eğitimi sırasında hem teorik, hem de uygulamalı olarak anlatılmaktadır $(2,13)$. Hemşirelik süreci hemşirelik öğrencilerinin sorun çözme becerilerini, yazılı ve sözel iletişim becerilerini, öğrendikleri kuramsal bilgiyi uygulama alanında kullanma becerilerini geliştirmelerine katkı sağlamaktadır (13). Teorik bilgi ve klinik deneyim eksikliği, hata yapmaktan korkma gibi çeşitli nedenlerle, hemşirelik bakımını planlama ve uygulama öğrenciler tarafından çok iyi anlaşılamamakta, zor bir uygulama olarak kabul edilmektedir (2). Yapılan çeşitli çalışmalarda hemşirelik öğrencilerinin meslek yaşamlarında önemli olduğunu $(2,4,8,14)$ düşünmekle birlikte, hemşirelik sürecine ilişkin bilgi ve uygulamalarında sorun yaşadıkları belirlenmiştir. Kolaycı, Özdemir, Tunca ve Atay'ın (2010) hemşirelik öğrencilerinin hemşirelik süreci ve bakım planına ilişkin görüşlerinin belirlenmesi amacı ile gerçekleştirdikleri araştırmada öğrencilerin \%33,3'ü hemşirelik sürecinin tanı koyma aşamasında sorun yaşadığını belirtmiştir (8). Keski ve Karadağ (2010) tarafından yürütülen araştırmada, öğrencilerin \%51,6'sı hemşirelik sürecinin bir aşamasında sorun yaşadığını belirtmiştir (4). Şendir ve ark. (2009)'nin çalışmasında, öğrencilerin en çok güçlük yaşadıkları süreç basamaklarının tanılama ve planlama aşamasındaki girişimlerin belirlenmesi bölümü olduğu, büyük bir kısmının değerlendirme aşamasını daha kolay buldukları belirlenmiştir (12). Güner ve Terakye (2000)'nin 196 hemşirelik son sınıf öğrencisi üzerinde yaptıkları bir çalışmada, etiyolojik faktörlerle birlikte tanıyı doğru belirleyebilen öğrenci oranının sadece \%14,71 olduğu saptanmıştır (15). Aynı çalışmada, öğrencilerin belirti ve bulguları etiyolojik faktör olarak ifade etmesi $(\% 40,6)$ ve problemi, verilen klinik duruma uygun ifade edememesi $(\% 36,7)$ en yaygın hatalar olarak saptanmıştır (15). Yönt ve ark. (2009)'nın hemşirelik öğrencilerinin kullandıkları hemşirelik tanılarının ve hemşirelik tanıları ile ilişkili görüşlerinin belirlenmesi amacıyla yaptıkları araştırmada, öğrencilerin $\% 76,9^{\prime}$ unun hemşirelik tanısının ne olduğunu bildiği, fakat \%31,5'inin hasta bakım gereksinimini hemşirelik tanısı olarak ifade etmekte sıkıntı yaşadığı belirlenmiştir (14). Aydın ve Akansel'in (2013) hemşirelik öğrencileri tarafından oluşturulan hemşirelik tanılarının NANDA taksonomisine 
uygunluğunu belirlemek amacıyla gerçekleştirdikleri araştırmada da öğrencilerin hemşirelik tanılarının isimlendirilmesinde sorun yaşadığı ve belirli tanıları daha sık kullandıkları belirlenmiştir (16).

Yaşanan sorunların gerçek nedenlerinin belirlenmesi problemin çözümü için önemlidir. Balık kılçı̆̆ı, problem çözmede kullanılan temel tekniklerden biridir. Balık kılçığı diyagramı, bir problemin olası tüm sebeplerini ve aralarındaki ilişkiyi net bir şekilde belirlemek için kullanılır. Problem belirlendikten sonra oluşturulan ve kullanıcıların problem için genel bir bakış açısı geliştirmesini sağlayan bir tekniktir $(17,18)$.

Bu bilgilerden yola çıkarak bu araştırma hemşirelik öğrencilerinin hemşirelik bakım planlarını hazırlarken yaşadıkları güçlüklerin kök nedenlerini belirlemek amacıyla planlanmıştır.

\section{Materyal ve metod}

Araştırmanın türü ve örneklemi

Bu çalışma 2015-2016 Eğitim öğretim yılı güz yarıyılında Hemşirelik Süreci dersini alan ve araştırmaya katılamaya gönüllü olan ve ikinci sınıfa kayıtlı bulunan 52 hemşirelik öğrencisi ile gerçekleştirilen tanımlayıcı tipte bir araştırmadır.

\section{Veri toplama yöntemi}

Hemşirelik Süreci dersi kapsamında öğrencilere bakım planı uygulama konusunda teorik bilgi verilmesinin yanı sıra, vaka çalışmaları yapılarak öğrencilerin bakım planı oluşturma becerileri geliştirilmesi hedeflendi. Öğrencilerden balık kılçı̆ı̆ diyagramı üzerinde bakım planı yaparken yaşadıkları güçlüklerin nedenlerini, araştırmacılar tarafından daha önce belirlenen dört temel başlık altında (insanlar, metot, materyal ve çevre) yazmaları ve bunu dönem ödevi olarak teslim etmeleri istendi.

\section{Verilerin değerlendirilmesi}

Verilerin değerlendirilmesinde SPSS 20,0 programı kullanıldı, sonuçlar sayı ve yüzde olarak verildi.

\section{Araştırmanın etik yönü}

Araştırmanın yürütülebilmesi ile ilgili kurum yönetiminden izin alındı. Öğrenciler çalışmanın amacı konusunda bilgilendirildi ve sözlü onamları alındı.

\section{Araştırmanının sınırlılıkları}

Araştırmanın sadece ikinci sınıf öğrencileri ile yapılmış olması araştırmanın sınırlıkları arasındadır.

\section{Bulgular}

Araştırmaya katılan öğrencilerin tamamını hemşirelik süreci dersi alan ve hemşirelik sürecini daha önce uygulama fırsatı bulan ikinci sınıf öğrencileri oluşturdu. Öğrencilerin yaş ortalaması $20,28 \pm 2,03$ olarak hesaplandı. Öğrencilerin $\% 69,2$ 'sinin ( $n=36)$ kadın, \%30,8'inin ( $n=16)$ erkek olduğu saptandı. Çalışmada elde edilen veriler doğrultusunda hemşirelik öğrencilerinin bakım planlarını oluştururken yaşadıkları güçlükler dört ana başlık altında toplandı. Bunlar;

1. İnsanlar (Öğrencilerin kendileri ile ilişkili, hastalar ile ilişkili, öğretim elemanı ve hemşirelerle ilişkili faktörler)

2. Metot (Analitik düşünme becerisine sahip olamamak, zamanı iyi kullanamamak, verilerin yetersiz olması vb.)

3. Malzeme (Klinik uygulamada kullanılan veri toplama formları)

4. Çevredir (Klinik ortamla ilişkili faktörler).

Öğrencilerin bakım planı yaparken yaşadıkları güçlükler Tablo 1'de verildi.

\section{Tartışma}

Hemşirelik süreci hemşirelik mesleğinin ayrılmaz ve önemli bir parçasıdır. Hemşirelik bakım planı geliştirmek ve hastanın bakımını bu doğrultuda sürdürmek hemşirelik mesleği içinde önemli uygulamalardır. Bakım planlarının, hem sağlıklı hem de hasta olan bireylerin bakımının planlanmasında kullanılması önerilmektedir (19).

Hemşirelikte bakım planı kullanılmasının hemşirelerin problem çözme becerilerine katkı sağladığı, karar verme ve analitik düşünme becerilerini de geliştirdiği belirtilmektedir $(20,21)$. Hemşirelik sürecinin tüm aşamalarının etkin bir şekilde çalıştığından emin olmak için klinik alanda kullanılması son derece önemlidir (21). Diğer yandan yapılan çalışmalarda kavram haritaları ile çalışmanın hemşirelik öğrencilerinde bakım planı ile çalışmaktan daha fazla yarar sağladığı da görülmektedir $(22,23)$. Hemşirelik öğrencileri bakım planı geliştirme ve bunu uygulamada bazı zorluklar yaşamaktadır (12). Çalışmalarda öğrencilerin hemşirelik sürecinin özellikle tanılama ve planlama bölümlerinde (12), belirti ve bulguları yanlış kullandıkları, problemi uygun şekilde tanımlayamadıkları (15), bakım gereksinimlerini hemşirelik tanısı olarak ifade etmede sorun yaşadıkları (14) belirtilmektedir. Hemşirelerle yapılan başka bir çalışmada hastadan veri toplamanın hemşireler tarafından da zor bir süreç olarak algılandığı görülmektedir (24). Bu sonuçlara bakarak hemşirelik bakım planı oluşturmakla ilgili sorunların öğrencilikten başlayıp 
Tablo 1. Hemşirelik öğrencilerinin bakım planı hazırlarken yaşadıkları güçlüklerin nedenleri

Sayı* Yüzde

(n) $\quad(\%)$

\section{INSANLAR}

Öğrencilerin kendileri ile ilişkili faktörler Bilgi eksikliği

$32 \quad 58,18$

Hasta ile iletişim kurmada güçlük yaşanması

$26 \quad 47,27$

Bakım planı yapmayı gereksiz görmek

$17 \quad 30,90$

Motivasyon eksikliğ

Hata yapma korkusu

$15 \quad 27,26$

$8 \quad 14,54$

Stres

$1 \quad 1,81$

\section{Hastalar ile ilişkili faktörler}

Hasta ile iletişimde engeller (entübasyon, yaşlılk vb.)

Hastanın konuşmak istememesi

Hastanın bilgi eksikliği (hastalık, tanı-tetkik vb.)

36,5

Hastanın negatif tutumı

Öğretim elemanları ile ilişkili faktörler

Öğretim elemanlarının beklentilerinin yüksek olması

$7 \quad 12,73$

Öğretim elemanlarının pozitif geri bildirim vermemesi

$5 \quad 9,09$

Negatif eleştirilere maruz kalmak

$4 \quad 5,48$

Hemşirelerle ilişkili faktörler

Klinik hemşirelerinin tutumları

$16 \quad 29,09$

\section{METOD}

Analitik düşünme becerisinde eksiklik (eğitim metodu)

$16 \quad 29,09$

Zamanı iyi kullanamamak (Zaman yönetim metodu)

$15 \quad 27,27$

Hasta kayıtlarına/dosyalarına erişimin güç olması

$14 \quad 25,45$

(Bilgi işlem sistemi, veri paylaşım güvenliği)

Verilerin yetersiz olması (Veri paylaşım metodu)

$13 \quad 23,63$

Teorik bilgiyi uygulamaya aktarmada eksiklik

$3 \quad 5,45$

(Uygulama metodu)

Çok sayıda konuyu çalışma zorunluluğunun olması

(Öğrenme metodu)

$3 \quad 5,45$

Çok sayıda konuyu çalışma zorunluluğunun olması (Öğrenme metodu)

\section{MALZEMELER}

Klinik uygulamada kullanan veri toplama formları ile ilişikli faktörler

Formların çok uzun ve kapsamlı olması

1323,63

Hastalara sorulması çok güç olan soruların varığı $\quad 12 \quad 21,81$

Formların çok detaylı ve karmaşık olması $\quad 5 \quad 9,09$

Terminolojinin anlaşılamaması

$3 \quad 5,45$

\section{4. ÇEVRE}

Klinik ortam ile ilişkili faktörler

Klinik uygulamada hemşirelik bakım planlarının etkin $\quad 27 \quad 49,09$

şekilde kullanıldığı görmemek

Klinik uygulamanın yoğun olması

1120,00

Materyal eksikliği

$9 \quad 16,36$

Klinik uygulama saatinin yetersiz olmas

10,90

Öğrencilerin klinik uygulamada kabul görememesi

$3 \quad 5,45$

*Birden fazla cevap verilmiştir. çalışma hayatında da önemli ölçüde sürdüğünü söylemek mümkündür. Problemlerin çözümünde problemin ne olduğunu bilmek yeterli değildir. Problemin analiz edilmesi ve gerçek iyileştirmeler için kök nedenlerin bulunarak ortadan kaldırılmaya çalışııması gerekir. Problem çözümünde kullanılan yöntemlerden biri olan balık kılçığı yöntemi bir problem ve bu problem ile ilişkili olabilecek nedenleri balık kılçığına benzer bir diyagram üzerinde sunmaktadır. Bu diyagram bireylerin problem ile ilişkili sistematik bir şekilde düşünmeleri ve problemin temel nedenlerini belirlemesine yardımcı olmakta, grup çalışmasını teşvik etmekte ve daha fazla çalışma için verilerin toplanması gereken alanları tanımlamaktadır (17).

Bu bilgilerden yola çıkarak, bakım planı hazırlama konusundaki güçlüklerin kök neden analizlerini belirlemek amacıyla gerçekleştirilen araştırmada elde edilen veriler insanlar, metod, malzeme ve çevre olmak üzere dört ana başlık altında tartışılmıştır.

\section{Insanlar ile ilișkili nedenler}

Bu çalışmada hemşirelik öğrencilerinin yarıdan fazlasının $(\% 58,18)$ bakım planı yapmakla ilgili bilgi eksikliği olduğu belirlenmiştir. Hemşirelik süreci hemşirelik eğitimi boyunca ve birinci sınıftan itibaren tüm hemşirelik eğitimcileri tarafından üzerinde önemle durulan bir konu olmakla birlikte, öğrencilerin bu konuda yetersiz bilgiye sahip olduklarını ifade etmeleri konunun öğrenciler tarafından yeterince özümsenmediğini düşündürmektedir. Hasta ile iletişim kurmak hastadan veri toplamanın en temel unsurlarından bir tanesidir. Etkisiz iletişim hem hemşire hem de hasta yönünden olumsuz sonuçlara yol açarak tedavi ve bakımın da olumsuz sonlanmasına yol açabilir (25-30). Bu çalışmada hasta ile iletişim kurma becerilerindeki eksikliklerin hemşirelik öğrencilerinin bakım planı geliştirmelerinin önünde önemli bir engel olduğu düşünülmüştür. Farklı çalışmalar yapılarak hemşirelik öğrencilerinin iletişim kurarken hangi hasta grubu ile güçlük yaşadıklarının ve bu güçlüğün yaşanmasında hangi faktörlerin etkili olduğunun belirlenmesi son derece önemlidir. Özellikle klinik uygulamaların ilk yıllında hasta ile iletişim sırasında bazı güçlüklerin olması normal kabul edilebilse de, ilerleyen süreçte bununla ilgili daha az sıkıntı olması beklenir. İletişimde verilen ve alınan mesajların her iki taraf tarafından doğru anlaşııma$\mathrm{sı}$, jest ve mimiklerin doğru kullanımı, aktif dinleme son derece önemli ayrıntılardır $(25,26)$. Hemşirelik eğitimi sırasında öğrencilerin bu unsurlara ne kadar dikkat ettikleri ve soru sorma, dinleme becerisi ve etkin iletişim tekniklerini kullanmada ne kadar başarılı olduklarını değerlendirecek çalışmaların yapılması konunun çözümü 
için bir adım olabilir. Bir çalışmada hasta simülasyonu uygulamasının hemşirelik öğrencilerinin gerçek hastalarla bir araya gelmesini, gerçek tıbbi durumlara ve olgularla bir arada olmanın hemşirelik öğrencilerinin bakım planı oluştururken yararlı olduğu belirtilmektedir (28). Bu tür farklı uygulamaların hemşirelik öğrencilerine farklı bakış açıları katacağı ve problem çözme becerilerini geliştireceği düşünülebilir. Hemşirelik öğrencilerine göre teorik bilgi ve uygulama arasındaki uçurum klinik uygulamalarda önemli bir problemdir (29). Özellikle klinik bilgi ve becerinin, kendini donanımlı hissetmemenin klinik uygulamalardaki farklı hastalara bakım vermek için yeterli olmaması hemşirelik öğrencilerinin anksiyetesini artıran bir durumdur (29). Bu çalışmada da hemşirelik öğrencilerinin hemşirelik sürecini uygulama konusunda motivasyon eksikliği, hata yapma korkusu ve stres deneyimledikleri belirlenmiştir.

Bu çalışmada hemşirelik öğrencilerinin çok az bir kısmı öğretim elemanlarının beklentilerinin yüksek olmasından $(\% 12,73)$, pozitif geri bildirim vermemelerinden $(\% 9,9)$ ya da negatif eleştiriler yaptıklarından $(\% 5,48)$ bahsetmektedir. Araştırma hemşirelik bölümünde okumakta olan tüm hemşirelik öğrencilerini kapsamadığından sonuçları genellemek mümkün değildir.

Klinik ortamda bulunmak, hemşirelik uygulamalarını gözlemek ve yapma fırsatı bulmak hemşirelik öğrencilerinin eğitiminde son derece önemli bir yere sahiptir (30). Bakım planı yapan hemşirelerin kendi profesyonel rollerine yönelik farkındalıklarının daha yüksek olduğunu, bakım planı yapma isteği olmayanların ise hastaya yaklaşımda daha çok medikal bakış açısını benimseme eğiliminde olduklarını belirtilmektedir (21). Görülen rol modeller, yapılan uygulamalar, klinik işleyişi gözlemleme olanağı öğrenciler için değerli birer deneyimdir. Baraki ve ark. (2017) çalışmasında yoğun kliniklerde çalışan hemşirelerin bakım planı uygulamakla ilgili sıkıntılar yaşadıkları ve önemli bir kısmının bakım planlarını kullanmadığı belirtilmektedir (31). Hemşirelerin eğitim düzeyi, konuyla ilgili farkındalıkları, becerileri $(31,32)$ işyerindeki çalışma atmosferi $(24,31)$, malzeme eksikliği, hasta yoğunluğunun fazla olması $(32,33)$ hemşirelik sürecinin uygulanmasındaki engeller arasında sıralanmaktadır $(24,34)$.

\section{Metod ile ilişkili nedenler}

Analitik düşünme becerisinin eksik olması $(\% 29,09)$, zamanı iyi kullanamamak, verilerin yetersiz olması hemşirelik öğrencilerinin kendileri ile ilgili ilettikleri nedenler arasında yer almaktadır. Öğrencilerin elde ettikleri verileri yorumlayamamaları onları hemşirelik bakım planı yaparken zorlayan bir unsur olduğu düşünülmektedir. Bu çalışmada öğrencilerin bazılarının klinik uygulamada geçirdiği zamanı etkin kullanamadığını ifade etmesi $(\% 27,27)$ ve hastalardan elde ettikleri verilerin yetersiz olması öğrencilerin kendilerinden beklenen hemşirelik bakım planları ile ilgili sorumlulukları yerine getirmede zorluk yaşamlarına yol açtığı düşünülmektedir. Bununla birlikte bakım planı yapmayı gereksiz görmek $(\% 30,90)$ hemşirelik öğrencilerinin güçlük yaşamalarına neden olan faktörler arasındadır. Bu çalışmada öğrencilerin bakım planlarını neden gereksiz gördükleri ile ilgili bir soru sorulmamıştır. Elde edilen bu sonuç öğrencilerin motivasyon eksikliğinin, veri toplamadaki eksikliklerinin, gördükleri rol modellerin ya da klinik uygulamalarda işleyişle ilgili bir sonuç olabilir. Bu çalışmada hasta dosyalarına ve hasta kayıtlarına ulaşmakla ilgili bazı güçlüklerin $(\% 25,45)$ ve materyal eksikliği $(\% 16,36)$ hemşirelik öğrencilerinin bakım planı oluşturmakta zorlanmalarına yol açtığı belirlenmiştir. Bu durum, klinik ortamdaki öğrencinin hastanın odasına gitmeden önce hastaya ait tıbbi kayıtları mutlaka görmekle ilgili bir çaba içinde olduklarını göstermektedir. Öğrencilerin bir kısmının neden özellikle öncelikli olarak tıbbi kayıtlara ulaşmak isteğinde olduklarını anlamak mümkün olmasa da; hastalarla ilgili olarak bazı somut verilere (laboratuvar, test sonuçları vb.) ulaşmanın, hastaya ait bazı tanı, yapılan tıbbi tedavi gibi uygulamalar hakkında bilgi sahibi olmanın kendilerini hastanın yanında daha rahat hissetmelerine yardımcı olduğu düşünülebilir. Jansson ve ark. (2009) çalışmasında medikal bakış açısıyla hastaya yaklaşan hemşirelerin daha çok somut veriler, tıbbi kayıtlar ve objektif test sonuçlarına yöneldiğini belirtmektedir (21). Aynı çalışmada hemşirelik bakış açısı ile yaklaşan hemşirelerin hemşirelik kayıtlarını temel aldığı ve aynı zamanda tıbbi kayıtları da bu sürece dahil ettiğini görmüşlerdir. Çalışmamızda hemşirelik öğrencilerin hasta kayıtlarına ve çeşitli materyallere ulaşmayı ciddi bir sorun olarak görmeleri onların hastalara daha medikal bir bakış açsısı ile yaklaşma eğiliminde olduklarını da göstermektedir. Hemşirelik bakım planlarında hasta bakımını üstlenen hemşirenin hastayı bütüncül olarak ele alması en temel hedeflerden bir tanesidir. Sadece belli yönleri ile hastayı ele almak hemşirelik bakımının doğasına aykırıdır. Bu çalışmada hemşirelik öğrencilerinin hasta ile iletişimde güçlük yaşamalarının $(\% 47,27)$ bakım planı oluşturmadaki engeller arasında önemli bir yer tuttuğu düşünüldüğünde, öğrencilerin hastaya holistik yaklaşmaktan çok belirti/bulgulara odaklanarak hareket ettikleri şeklinde yorumlanabilir. Bu konu hem hemşirelerde hem de hemşirelik öğrencilerinde özellikle araştırılması gereken bir konudur. 
Bu nedenle hemşirelik öğrencilerine tıbbi kayıtların hemşirelik sürecine nasıl yansıtılması gerektiği de ele alınması gereken ve araştırılması gereken bir diğer konudur.

\section{Malzeme ile ilişkili nedenler}

$\mathrm{Bu}$ çalışmada hemşirelik öğrencilerinin klinik uygulama sırasında kullandıkları formlara ilişkin belirttikleri bazı unsurların (formların uzun ve kapsamlı olması, hastalara sormakta güçlük yaşadıkları soruların varlığı, formlardaki detay ve karmaşıklık, formlardaki terminolojinin anlaşılamaması) bakım planı oluşturmakta güçlük yarattığı belirlenmiştir. Hemşirelik klinik eğitiminde kullanılan veri toplama formlarının oluşturulmasında yaygın olarak hemşirelik kuramcıları tarafından geliştirilen kuramlar rehber alınmaktadır. Verilerin bir sistematik doğrultusunda toplanması öğrenciye de daha sistematik düşünme, analiz etme ve hasta bakımını planlama becerisini kazandırmak amaçlanmaktadır. Ancak bu formların öğrenciler tarafından ne kadar anlaşıdığı, hangi alanların problem oluşturduğunu belirlemeye yönelik bir araştırmaya rastlanmamıştır. Hastalara yönelik verilerin eksik olması ya da hiç olmaması, verileri yorumlamadaki eksiklikler, elde edilen verilerin nasıl ve nerede kullanılacağını bilememek bakım planının gerçek amacına ulaşmasını engellemektedir. Bu durumun öğrencilerin hem klinik eğitimdeki zamanı etkin kullanmayı önlediği hem de öğrencilerin asıl hedeflenen konuları öğrenmelerinin önünde bir engel olduğu düşünülmektedir. Bu nedenle öğretim elemanlarının eğitim öğretim etkinliklerini planlarken, kullanılacak materyalleri tasarlarken amaç ve hedefleri dikkate almaları son derece önemlidir.

\section{Çevre ile ilişkili nedenler}

Yapılan farklı çalışmalarda hemşirelik öğrencilerinin klinik uygulamalarda anksiyete yaşadıkları ve bunun özellikle ilk sınıflarda okumakta olan öğrenciler tarafından yoğun olarak deneyimlendiği belirtilmektedir $(35,36)$. Özellikle klinik çalışanları tarafından kabul görmemek, kendini oraya ait

\section{Kaynaklar}

1. Karaca A, Yıldııım N, Ankaralı H, Açıkgöz F, Akkuş D. Hemşirelik Eğitimi Stres Ölçeği'nin Türkçeye Uyarlanması. Hemşirelikte Araştırma Geliştirme Derg 2014;16:29-40. https://toad.halileksi.net/ sites/default/files/pdf/hemsirelik-egitimi-stres-olcegi-toad.pdf

2. Can G, Erol O. Nursing Students' Perceptions About Nursing Care Plans: A Turkish Perspective. Int J Nurs Pract 2012;18:12-9. [CrossRef]

3. Collins A. Effect of Continuing Nursing Education on Nurses' Attitude Toward and Accuracy of Nursing Diagnosis. Int J Nurs Knowl 2013;24:122-8. [CrossRef]

4. Keski Ç, Karadağ A. Hemşirelik Son Sınıf Öğrencilerinin Hemşirelik Süreci Hakkındaki Bilgi Düzeylerinin İncelenmesi. HEMAR-G 2010;1:41-52. http://hemarge.org.tr/ckfinder/userfiles/ files/2010/2010-vol12-sayi1-233.pdf hissetmemek, eleştirilere maruz kalmak öğrencilerin sıklıkla belirttiği olumsuzluklar arasında yer almaktadır $(35,37)$. Bu çalışmada hemşirelik bakım planlarının hasta bakımında etkin olarak kullanıldığına tanık olmamak öğrencilerin yarıya yakını tarafından dile getirilen bir unsurdur $(\% 49,09)$. Özellikle teorik olarak öğrenilen bilgilerin klinik ortamda uygulandığını görmek öğrencilerin kafalarındaki bu konuya ilişkin soru işaretlerinin giderilmesinde son derece etkilidir. Türkiye'de yapılan bazı çalışmalarda, hemşirelerin bakım planı yaparken güçlük yaşadıklarını, büyük çoğunluğunun hemşirelik tanısını belirlemede (33,38-40), belirlenen hemşirelik tanılarına özgü uzun vadeli amaçları ve hemşirelik girişimlerini belirlemede (40), veri toplamada, hemşirelik girişimlerini yazmada, sonuçlarını değerlendirmede (33) zorlandıkları belirtilmektedir. Bu sonuçlar öğrencilerin klinik ortamda bakım planlarının aktif şekilde ve etkin olarak kullanıldığını görmemelerini destekler niteliktedir.

\section{Sonuç ve öneriler}

Hemşirelik uygulamalarının kanıta dayalı olması, yapılan uygulamaların kayıt edilmesi (41), sonuçlarının değerlendirilmesi hem sağlık çalışanı olarak hemşireyi yasal anlamda koruyan hem de hasta güvenliğinin sağlanması için son derece önemlidir. 2007 yılında Hemşirelik Kanunundaki yasal düzenleme de bunu destekler niteliktedir (Değişik: 25/4/2007-5634/3 md.) (9).

Hemşirelik öğrencilerinin hemşirelik bakım planlarını oluştururken kendilerinden çeşitli konularda güçlük yaşadıkları görülmektedir. Öğrenme deneyimlerinin öğrenci üzerindeki etkileri sadece eğitim süreci ile sınırlı kalmayıp ve meslek yaşantısını şekillendirmede de katkı sağlamaktadır. Özellikle olumsuz öğrenme yaşantıların derin izler bıraktığını, öğrencinin öğrenmeye olan isteğini ve cesaretini kırdığı düşünüldüğünde bunun sadece tek boyutlu bir sorun olmadığını hem eğitimcilerin hem de klinik alanda çalışan hemşirelere ciddi sorumluluklar düştüğünü unutmamak gereklidir.

5. Kaya N. Hemşirelik Süreci Hemşirelik Tanılaması. Hemşirelik Esasları Hemşirelik Bilimi ve Sanatı kitabı. İçinde: Aştı TA, Karadaği editörler. İstanbul: Akademi Basın ve Yayıncılık; 2012. s.137-75.

6. Taşçı S. Hemşirelikte Problem Çözme Süreci. Sağlık Bilimleri Derg 2005;14(Ek Sayı: Hemşirelik Özel Sayısı):73-8. http://sagens.erciyes. edu.tr/dergi/hemsire/Sultan2.pdf

7. Kaya N. Hemşirelik Süreci. İç Hastalıkları Hemşireliği Kitabı. İstanbul: Akademi Basın ve Yayıncılık; 2013. s.45-78.

8. Kolancı S, Özdemir H, Tunca A, Atay S. Hemşirelik Öğrencilerinin Hemşirelik Süreci ve Bakım Planına İlişkin Görüşlerinin Incelenmesi. Maltepe üniversitesi Hemşirelik Bilim ve Sanatı Derg 2010;Sempozyum Özel Sayısı: 339.

9. Resmi Gazete, 2007. 6283 Sayılı Hemşirelik Kanunu. http://www.ttb. org.tr/mevzuat/index.php?option=com_content\&view=article\&id= 502:hemrel-kanunu-6283\&catid $=1$ :yasa\&ltemid $=28$ 
10. Resmi Gazete, 2010. Hemşirelik yönetmeliği. http://www.ttb.org.tr/ mevzuat/index.php?option=com _content \&view=article \&id=745: hemrel-yetmel\&catid=2:ymelik\&ltemid=33

11. Sağlıkta Kalite Standartları. http://www.performans.saglik.gov. tr/content/files/hizmet_kalite__ standartlari_2011/hastane_hks/ hkskitap.pdf

12. Şendir M, Acaroğlu R, Aktaş A. Hemşirelik Yüksekokulu Son Sınıf Öğrencilerinin Hemşireliğe İlişkin Görüşleri. İstanbul Üniversitesi Florence Nightingale Hemşirelik Yüksekokulu Derg 2009;17:166-173.

13. Kaya N, Kaya H, Babadağ K. Öğrencilerin Hemşirelik Süreci Formlarının Planlama Aşamasının İncelenmesi. İstanbul Üniversitesi Florence Nightingale Hemşirelik Yüksekokulu Derg 2004;13:79-90.

14. Yönt GH, Khorshid L, Eşer I. Examination of Nursing Diagnoses Used by Nursing Students and Their Opinions About Nursing Diagnoses. Int J Nurs Terminol Classif 2009;20:162-8. [CrossRef]

15. Güner P,Terakye G. HemşirelikYüksekokulları Son Sınıf Öğrencilerinin Hemşirelik Tanılarını Belirleyebilme Düzeyleri. Cumhuriyet Üniversitesi Hemşirelik Yüksekokulu Derg 2000;4:9-15. http:// eskidergi.cumhuriyet.edu.tr/makale/2.pdf

16. Aydın N, Akansel A. Determination of Accuracy of Nursing Diagnoses Used by Nursing Students in Their Nursing Care Plans. Int J Caring Sci 2013;6:252-7. https://pdfs.semanticscholar.org/ffd5/35048c17be8a 3e3d3f7081125a203749c9fb.pdf

17. Ilie G, Ciocoiu CN. Application of Fishbone Diagram to Determine the Risk of an Event with Multiple Causes. Manage Res Prac 2010;2:1-20.

18. Alcan Z, Tekin DE, Civil SÖ. Hasta Güvenliği Beklenmedik Olaylarda Hasta Güvenliği. İstanbul: Nobel Tıp Kitabevleri; 2012. p.189-2016.

19. The Nursing Process. http://www.nursing-theory.org/articles/The Nursing_Process.php

20. Yıldırım B, Özkahraman Ş. Critical Thinking in Nursing Process and Education. Int J Hum Soc Sci 2011;1:257-62. https://www.ijhssnet. com/journals/Vol_1_No_13_Special_Issue_September_2011/34. pdf

21. Jansson I, Pilhammar E, Forsberg A. Obtaining a Foundation for Nursing Care at the Time of Patient Admission: A Grounded Theory Study. Open Nurs J 2009;3:56-64. [CrossRef]

22. Sinatra-Wilhelm T. Nursing Care Plans Versus Concept Maps in the Enhancement of Critical Thinking Skills in Nursing Students Enrolled in a Baccalaureate Nursing Program. Creative Nurs 2012;18:78-84. [CrossRef]

23. Aein F, Aliakbari F. Effectiveness of Concept Mapping and Traditional Linear Nursing Care Plans on Critical Thinking Skills in Clinical Pediatric Nursing Course. J Educ Health Promot 2017;6:13. [CrossRef]

24. Mahmoud MH, Bayoumy HM. Barriers and Facilitators for Execution of Nursing Process from Nurses' Perspective. Int J Adv Res 2014;2:30015. http://www.journalijar.com/uploads/414_IJAR-2663.pdf

25. Terakye G. Hemşirelikte Illetişim ve Hasta Hemşire İlişkileri. Ankara: Aydoğdu Ofset; 1994.s.1-141. https://sbu.saglik.gov.tr/Ekutuphane/ kitaplar/200701101555430hemsirekikkitap.pdf

26. Temel $M$, Şişman FN. Iletişim Becerileri Eğitiminin Hemşirelik Öğrencilerinin Sanal ve Kişilerarası İlişkilerine Etkisi. Sağlık Bilimleri ve Meslekleri Derg 2017;4:171-9.

27. Sögüt $S$, Cangöl E, Dinç A. Hemşirelik Öğrencilerinin Illetişim Beceri Düzeylerinin Belirlenmesi. Researcher: Social Science Studies 2018;6:272-80. [CrossRef]
28. Karadağ M, Çalışkan N, İser O. Effects of Case Studies and Simulated Patients on Students' Nursing Care Plans. Int J Nurs Knowl 2016;27:87-94. [CrossRef]

29. Sharif F, Masoumi S. A Qualitative Study of Nursing Student Experiences of Clinical Practice. BMC Nurs 2005;4:1-7. [CrossRef]

30. Jamshidi N, Molazem Z, Sharif F, Torabizadeh C, Kalyani MN. The Challenges of Nursing Students in the Clinical Learning Environment: A Qualitative Study. Sci World J 2016;1-7. [CrossRef]

31. Baraki Z, Girmay F, Kidanu K, Gerensea H, Gezehgne D, Teklay H. A Cross Sectional Study On Nursing Process Implementation and Associated Factors Among Nurses Working in Selected Hospitals of Central and Northwest Zones, Tigray Region, Ethiopia. BMC Nurs 2017;16:1-9. [CrossRef]

32. Hagos F, Alemseged F, Balcha F, Berhe S, Aregay A. Application of Nursing Process and Its Affecting Factors among Nurses Working in Mekelle Zone Hospitals, Northern Ethiopia. Nursing Res Prac 2014;24:1-8. [CrossRef]

33. Zaybak A, Özdemir H, Erol A, İsmailoğlu EG. An Exploration of Nursing Student's Clinical Decision Making Process. Int J Nurs Knowl 2017;29:210-6. [CrossRef]

34. Afolayan JA, Donald B, Baldwin DM, Onasoga O, Babafemi A. Evaluation of the Utilization of Nursing Process and Patient Outcome in Psychiatric Nursing: Case Study of Psychiatric Hospital Rumuigbo, Port Harcourt. Adv Appl Sci Res 2013;4:34-43. http://www.imedpub. com/articles/evaluation-of-the-utilization-of-nursing-process-andpatient-outcomein-psychiatric-nursing-case-study-of-psychiatrichospitalrumui.pdf

35. Öner Altıok H, Üstün B. Hemşirelik Öğrencilerinin Stres Kaynakları. Kuram ve Uygulamada Eğitim Bilimleri 2013;13:74766. https://www.researchgate.net/profile/Hatice_Oener/ publication/286164433_The_Stress_Sources_of_Nursing Students/links/5c52cade299bf12be3eff9d3/The-Stress-Sources-ofNursing-Students.pdf

36. Karagözoğlu Ş, Özden D, Türk G, Yıldız FT. Klasik ve Entegre Müfredat Programı Hemşirelik Öğrencilerinin İlk Klinik Uygulamada Yaşadıkları Kaygı, Klinik Stres Düzeyi ve Etkileyen Bazı Faktörler. DEUHYO ED 2014;7:266-74.

37. Aydın MF, Argun MŞ. Bitlis Eren Üniversitesi Sağlık Yüksekokulu Hemşirelik Bölümü Öğrencilerinin Hastane Uygulamalarından Beklentileri ve Karşılaştıkları Sorunlar. ACU Sağlık Bil Derg 2010;1:209-13. http://acibadem.dergisi.org/uploads/pdf/pdf_ AUD_47.pdf

38. Andsoy II, Güngör T, Dikmen Y, Nabel EB. Hemşirelerin Bakım Planını Kullanırken Yaşadıkları Güçlükler. Çağdaş Tıp Derg 2013;3:88-94. https://dergipark.org.tr/tr/download/article-file/81836

39. Gök Özer F, Kuzu N. Öğrencilerin Bakım Planlarında Hemşirelik Süreci ve NANDA Tanılarını Kullanma Durumları. Ege Üniversitesi Hemşirelik Yüksek Okulu Derg 2006;22:69-80. https://dergipark.org. $\mathrm{tr} / \mathrm{tr} /$ download/article-file/835998

40. Karadokovan A, Usta Yeşilbalkan Ö. Öğrencilerin Nörolojik Hastalarda Saptadıkları NANDA Hemşirelik Tanılarının İncelenmesi. Atatürk Üniversitesi Hemşirelik Yüksekokulu Derg 2004;7:1-7. https://dergipark.org.tr/en/download/article-file/29236

41. Benedet SA, Gelbcke FL, Amante LN, Padilha MIS, Pires DP. Nursing Process: Systematization of the Nursing Care Instrument in the Perception of Nurses. Care Online 2016;8:4780-8. [CrossRef] 